\section{Pengaruh Pupuk Hayati Terhadap Pertumbuhan Bibit Kelapa Sawit (Elaeis guineensis Jacq.) pada Pembibitan Awal}

\author{
Muh. Yusuf Indris', Irwan Halid², Sukriming Sapareng ${ }^{3}$ \\ Program Studi Agroteknologi \\ Universitas Andi Djemma Palopo 1,2,3
}

Email: miming.mlgke@gmail.com³

\begin{abstract}
Abstrak. Penelitian ini bertujuan untuk mengetahui efektifitas mikroba penambat $\mathrm{N}_{2}$ yang terdapat dalam pupuk organik hayati pada empat taraf dosis pemupukan nitrogen dalam meningkatkan keragaan bibit kelapa sawit. Percobaan dilakukan dalam bentuk eksperimen menggunakan Rancangan Acak Kelompok dengan 2 faktor yaitu pupuk organik hayati dan pupuk nitrogen. Faktor pertama dengan tiga taraf perlakuan yaitu tanpa pupuk organik hayati, Pupuk organik dari kotoran sapi (Agro Flower) $1 \mathrm{~g} / \mathrm{kg}$ Tanah dan Pupuk organik hayati (Biost) $1 \mathrm{~g} / \mathrm{kg}$ Tanah. Sedangkan faktor kedua terdiri dari empat taraf yaitu tanpa pupuk $\mathrm{N}$, pupuk $\mathrm{N} 50 \%$ dari dosis standar, pupuk N $100 \%$ dari dosis standar, dan pupuk N $150 \%$ dari dosis standar. Setiap perlakuan diujikan terhadap 4 bibit kelapa sawit dan diulang sebanyak 3 kali, sehingga diperoleh 144 tanaman percobaan. Pengamatan yang dilakukan yaitu peubah keragaan tanaman meliputi tinggi tanaman, jumlah daun, dan diameter batang. Peubah kadar hara tanaman meliputi kadar hara $\mathrm{N}$ total, kadar hara $\mathrm{P}$, dan kadar hara K. Hasil penelitian menunjukkan bahwa mikrob penambat $\mathrm{N}$ yang terdapat didalam pupuk organik hayati meningkatkan tinggi tanaman dan diameter batang yang nyata pada pembibitan kelapa sawit. Penggunaan pupuk $\mathrm{N}$ dosis $100 \%$ bersama pupuk organik hayati menunjukkan hasil keragaan tanaman terbaik.
\end{abstract}

Kata Kunci: Pupuk Hayati, Bibit Kelapa Sawit, Pre Nursery.
INDONESIAN JOURNAL OF FUNDAMENTAL SCIENCES (IJFS)

\section{E-ISSN: 2621-6728 \\ P-ISSN: 2621-671X}

Submitted: June $11^{\text {th }}, 2019$

Accepted : August, 13 ${ }^{\text {th }}, 2019$

Abstract. This study aims to determine the effectiveness of N2-fixing microbes contained in organic organic fertilizers at four levels of nitrogen fertilizer application in increasing the performance of oil palm seedlings. The experiment was carried out in the form of an experiment using a Randomized Block Design with 2 factors: organic organic fertilizer and nitrogen fertilizer. The first factor with three levels of treatment, namely without organic biological fertilizer, Organic fertilizer from cow dung (Agro Flower) $1 \mathrm{~g} / \mathrm{kg}$ of Soil and Organic organic fertilizer (Biost) $1 \mathrm{~g} / \mathrm{kg}$ of Soil. While the second factor consists of four levels, namely without $N$ fertilizer, $N$ fertilizer $50 \%$ of the standard dose, $N$ fertilizer $100 \%$ of the standard dose, and $N$ fertilizer of $150 \%$ of the standard dose. Each treatment was tested on 4 oil palm seedlings and repeated 3 times, so that 144 experimental plants were obtained. The observations made were the variable plant performance includes plant height, number of leaves, and stem diameter. Variants of plant nutrient levels included total $N$ nutrient levels, $P$ nutrient levels, and $K$ nutrient levels. The results showed that $\mathrm{N}$ inhibiting microbes contained in organic organic fertilizer increased plant height and stem diameter significantly in oil palm nurseries. The use of a $100 \%$ dose of $N$ fertilizer together with organic biofertilizers shows the best crop performance results. 


\section{PENDAHULUAN}

Pemakaian pupuk anorganik secara terus menerus dengan dosis yang berlebihan memiliki dampak buruk terhadap kerusakan lingkungan dan penurunan keanekaragaman hayati tanah, sehingga perlu dicari alternatif lain agar produksi pertanian bisa ditingkatkan tanpa bergantung sepenuhnya pada pemakaian pupuk anorganik. Salah satu solusi adalah penggunaan pupuk organik hayati (Bio organic fertilizer) yang diperkaya mikrob tanah bermanfaat. Mikrob tanah diketahui dapat memproduksi fitohormon yang berfungsi untuk meningkatkan pertumbuhan perakaran, pertumbuhan tajuk dan kesehatan tanaman (Rizwan dan Mahmood, 2017). Menurut Yue et al. (2015), aplikasi pupuk organik hayati untuk menurunkan pemakaian pupuk anorganik penting dilakukan untuk melindungi lingkungan dari dampak buruk pupuk anorganik yang digunakan berlebihan.

Pupuk organik hayati adalah kombinasi antara pupuk mikroba dan pupuk organik. Pupuk ini terbuat dari bahan-bahan alami seperti pupuk kandang, kompos dan kascing serta diperkaya dengan mikroba hidup yang memiliki peranan positif bagi tanaman. Pupuk hayati merupakan mikroba hidup yang diberikan kedalam tanah sebagai inokulan menyediakan unsur hara tertentu bagi tanaman. Beberapa mikroorganisme tanah seperti Rhizobium, Azospirillum, Bacillus, Bukholderia, Azotobacter, mikroba pelarut fosfat, bakteri penambat $\mathrm{N}_{2}$, Mikoriza, Tricodherma sp dan mikroba tanah lainnya adalah contoh mikroba yang sering digunakan untuk pupuk hayati dan sudah banyak tersedia dipasaran. Komunitas mikroba dapat berperan dalam pertumbuhan tanaman melalui beberapa mekanisme antara lain meningkatkan ketersediaan unsur hara didalam tanah, meningkatkan kemampuan bersaing terhadap hama dan penyakit yang ditularkan melalui perakaran (Li et al., 2018) serta untuk meningkatkan unsur-unsur hara di dalam tanaman.

Pemakaian pupuk organik hayati yang diaplikasikan dengan tepat dan benar akan berpengaruh positif terhadap ketersediaan unsur hara, ketahanan terhadap serangan penyakit dan meningkatkan kesehatan tanah sehingga pertumbuhan tanaman akan lebih baik dan hasil produksi dapat ditingkatkan. Pupuk organik hayati mampu meningkatkan efisiensi serapan hara, memperbaiki pertumbuhan dan meningkatkan komponen hasil produksi tanaman serta dapat meningkatkan ketahanan fisik tanaman terhadap serangan hama dan penyakit (Agung dan Rahayu, 2004). Lee et al. (2000) mengungkapkan interaksi mikroba penambat $N_{2}$ dengan tanaman inang merupakan salah satu contoh peningkatan kualitas tanaman oleh mikroba. Oleh sebab itu penelitian tentang pemanfaatan mikroba untuk budidaya perkebunan harus terus diteliti untuk mendapatkan hasil yang lebih baik dan optimal.

\section{METODE PENELITIAN}

Penelitian dilaksanakan pada lahan milik petani di Desa Pattimang, Kecamatan Malangke Kabupaten Luwu Utara Provinsi Sulawesi Selatan. Percobaan dilakukan dalam bentuk eksperimen menggunakan Rancangan Acak Kelompok (RAK) faktorial dengan 2 faktor, yaitu (I) pupuk organik hayati dan (II) pupuk nitrogen (N), dengan taraf sebagai berikut:

Faktor I. Pupuk organik hayati $(\mathrm{H})$

$\mathrm{H}_{\mathrm{O}}=$ Tanpa pupuk organik hayati

$\mathrm{H}_{1}=$ Pupuk organik dari kotoran sapi (Agro Flower) $1 \mathrm{~g} / \mathrm{kg}$ Tanah 
$\mathrm{H}_{2}=$ Pupuk organik hayati (Biost) $1 \mathrm{~g} / \mathrm{kg}$ Tanah

Faktor II. Pupuk Nitrogen $(\mathrm{N})$

$\mathrm{N}_{\mathrm{o}}=$ Tanpa pupuk $\mathrm{N}$

$\mathrm{N}_{1}=$ Pupuk $\mathrm{N} 50 \%$ dari dosis standar

$\mathrm{N}_{2}=$ Pupuk N $100 \%$ dari dosis standar

$\mathrm{N}_{3}=$ Pupuk $\mathrm{N} 150 \%$ dari dosis standar

Setiap perlakuan diujikan terhadap 4 bibit kelapa sawit dan diulang sebanyak 3 kali, sehingga diperoleh 144 tanaman percobaan. Pada aplikasi pemupukan dilakukan juga pemupukan dasar (Urea, $\mathrm{KCl}$ dan Kiserit-MgO) berdasarkan dosis anjuran teknologi budidaya kelapa sawit (Kiswanto et al. 2013).

\section{Penanaman Kecambah}

Sebelum kecambah ditanam, terlebih dahulu kecambah didistribusikan dan diletakkan di atas permukaan media tumbuh masing-masing baby polybag sampai selesai agar tidak terlewat pada saat penanaman. Selanjutnya, kecambah diangkat menggunakan tangan kiri kemudian ibu jari tangan kanan sebagai pelubang tanam yang ditahan oleh jari telunjuk ditusukkan ke media tumbuh sedalam $2 \mathrm{~cm}$. Kecambah yang sudah terlihat jelas plumula dan radikula ditanam sedalam $2 \mathrm{~cm}$ di bawah permukaan tanah. Pos|isi radikula di bawah dan plumula di atas, selanjutnya ditutup media tumbuh. Sebelum kecambah ditanam, kecambah terlebih dahulu disemprot fungisida berbahan aktif mankozeb dengan konsentrasi 0,3 $\mathrm{g} \mathrm{liter}{ }^{-1}$ air. Setelah selesai semua kecambah ditanam, media tumbuh disiram hingga mencapai kondisi kapasitas lapang.

\section{Pemeliharaan}

Penyiraman dilakukan setiap hari sebanyak dua kali (pagi dan sore hari) sampai mencapai kapasitas lapang. Selanjutnya penyiraman berdasarkan kekurangan air yang mencapai kapasitas lapang. Percobaan dilakukan pengendalian hama dan penyakit apabila bibit kelapa sawit terserang hama dan penyakit. Bila ada serangan hama disemprotkan insektisida berbahan aktif lamda sihalotrin konsentrasi 3 ml liter 'air dan bila terkena serangan jamur disemprotkan fungisida berbahan aktif mankonzeb $3 \mathrm{ml} \mathrm{liter}^{-1}$ air. Penyemprotan dilakukan satu minggu sekali sampai tidak ada gejala serangan hama dan penyakit.

\section{Pengamatan}

Pengamatan dilakukan pada saat kecambah ditanam selama satu bulan setelah tanam (BST), bibit sudah menghasilkan 1-2 helai daun dilakukan pengamatan di pre nusery. Pengamatan yang dilakukan yaitu peubah keragaan tanaman (tinggi tanaman, jumlah pelepah daun, diameter batang), serta peubah kadar hara tanamn (kadar $\mathrm{N}$ total, kadar hara $\mathrm{P}$, kadar hara $\mathrm{K}$ ).

\section{HASIL DAN PEMBAHASAN}

Hasil analisa statistik pada keragaan tanaman 12 MST (Tabel 1) menunjukkan hasil yang berbeda nyata pada tinggi tanaman dan diameter batang. Hal ini diduga karena pupuk $\mathrm{N}$ dalam pupuk hayati yang diberikan dalam bentuk NH digunakan oleh mikrob tanah untuk mendekomposisi bahan organik atau $\mathrm{C}$ Organik. Jumlah $\mathrm{N}$ yang dimineralisasi dalam kondisi aerobik (lahan kering) lebih kecil daripada kondisi 
anaerobik ( Wu, 2017). Kandungan $\mathrm{N}$ yang tersedia bagi tanaman sangat berpengaruh terhadap kemampuan tanaman untuk berkembang salah satunya dalam pertumbuhan pelepah daun tanaman. Nitrogen berperan utama dalam pertumbuhan daun dan batang, juga keseluruhan tubuh tanaman serta vigor tanaman (Nan et al., 2018).

Analisa keragaan tinggi tanaman menunjukkan hasil statistik yang berbeda nyata antar perlakuan dengan hasil tertinggi ditunjukkan oleh perlakuan pupuk organik hayati dengan pupuk N $100 \%$, sedangkan hasil terendah ditunjukkan oleh perlakuan tanpa penggunaan pupuk organik/hayati. Hasil terendah tersebut diakibatkan asupan $\mathrm{N}$ tanaman tidak terdistribusi dengan baik sehingga pertumbuhan tanaman tidak optimal. Roca et al. (2018) menyatakan keberadaan $\mathrm{N}$ sangat penting dalam pertumbuhan tanaman karena kedudukannya dalam proses biokimia tanaman sebagai unsur esensial pada pembentukan sel, penyusunan protein, sitoplasma, klorofil dan komponen sel lainnya. Hal tersebut juga mengakibatkan proses fotosintesis tidak berjalan optimal sehingga berakibat langsung pada pertumbuhan tanaman. $T$

Tabel 1. Pengaruh pupuk organik hayati pada bibit kelapa sawit terhadap tinggi tanaman, diameter batang dan jumlah pelepah daun pada umur 12 MST

\begin{tabular}{lccc}
\hline \multicolumn{1}{c}{ Perlakuan } & $\begin{array}{c}\text { Tinggi } \\
\text { Tanaman }(\mathrm{cm})\end{array}$ & $\begin{array}{c}\text { Diamter } \\
\text { Batang (mm) }\end{array}$ & $\begin{array}{c}\text { Pelepah / } \\
\text { Tanaman }\end{array}$ \\
\hline Pengaruh Tunggal & & & \\
Tanpa pupuk organik/hayati & $16.11^{\mathrm{b}}$ & $39.21^{\mathrm{c}}$ & $7.2^{\mathrm{a}}$ \\
Pupuk organik & $17.43^{\mathrm{ab}}$ & $41.34^{\mathrm{ab}}$ & $7 \cdot 3^{\mathrm{a}}$ \\
Pupuk organik hayati & $17.55^{\mathrm{ab}}$ & $40.89^{\mathrm{bc}}$ & $7.2^{\mathrm{a}}$ \\
\hline Pengaruh Kombinasi & & & \\
Tanpa pupuk organik/hayati & $14.98^{\mathrm{b}}$ & $39.65^{\mathrm{bc}}$ & $7.2^{\mathrm{a}}$ \\
Pupuk N (dosis 50\%) & $16.22^{\mathrm{b}}$ & $40.31^{\mathrm{bc}}$ & $6.6^{\mathrm{a}}$ \\
Pupuk N (dosis 100\%) & $16.74^{\mathrm{ab}}$ & $41.87^{\mathrm{ab}}$ & $7.4^{\mathrm{a}}$ \\
Pupuk N (dosis 150\%) & $16.43^{\mathrm{b}}$ & $41.27^{\mathrm{ab}}$ & $7.3^{\mathrm{a}}$ \\
Pupuk Organik & $15.34^{\mathrm{b}}$ & $41.26^{\mathrm{bb}}$ & $6.8^{\mathrm{a}}$ \\
Pupuk Organik + Pupuk N (dosis 50\%) & $17.45^{\mathrm{ab}}$ & $39.56^{\mathrm{c}}$ & $7.7^{\mathrm{a}}$ \\
Pupuk Organik + Pupuk N (dosis 100\%) & $18.14^{\mathrm{a}}$ & $42.64^{\mathrm{a}}$ & $7.6^{\mathrm{a}}$ \\
Pupuk Organik + Pupuk N (dosis 150\%) & $17.88^{\mathrm{ab}}$ & $42.67^{\mathrm{a}}$ & $7.4^{\mathrm{a}}$ \\
Pupuk Organik Hayati & $17.98^{\mathrm{ab}}$ & $40.01^{\mathrm{bc}}$ & $7.1^{\mathrm{a}}$ \\
Pupuk Organik Hayati + Pupuk N (dosis & $16.32^{\mathrm{b}}$ & $38.79^{\mathrm{c}}$ & $7.2^{\mathrm{a}}$ \\
50\%) & & & \\
Pupuk Organik Hayati + Pupuk N (dosis & $18.11^{\mathrm{a}}$ & $43.45^{\mathrm{a}}$ & $6.4^{\mathrm{a}}$ \\
100\%) & & & \\
Pupuk Organik Hayati + Pupuk N (dosis & $17.32^{\mathrm{ab}}$ & $42.24^{\mathrm{a}}$ & $7.1^{\mathrm{a}}$ \\
150\%) & & & \\
\hline
\end{tabular}

Keterangan : angka-angka yang diikuti oleh huruf yang sama pada kolom yang sama berbeda tidak nyata menurut uji Duncan Multiple Range Test $5 \%$.

Pada analisa pengaruh tunggal menunjukkan penggunaan pupuk organik/hayati selalu menunjukkan hasil yang lebih baik dibandingkan tanpa penggunaan pupuk organik/hayati. Hal ini membuktikan penggunaan pupuk 
organik/hayati dapat meningkatkan keragaan tanaman. Memasukan bahan organik ke dalam tanah dapat memperbaiki struktur tanah melalui peningkatan agregat yang mempengaruhi infiltrasi air, retensi air, drainase, aerasi, suhu dan penetrasi akar ( $\mathrm{Wu}$, 2017). Pemberian unsur-unsur bahan organik ke dalam tanah akan memperbaiki agregasi tanah dan tanah akan menjadi gembur sehingga dapat mendukung secara optimal pertumbuhan keragaan tanaman. Bahan organik mempengaruhi produktivitas tanah melalui mineralisasi zat gizi, kapasitas tukar kation, kapasitas memegang air dan kemampuannya untuk memperbaiki sifat fisik tanah (Nan et al., 2018).

Hasil uji statistik yang disajikan pada Tabel 2 mengenai pengaruh pemberian pupuk organik hayati terhadap serapan hara tanaman dari tiga parameter pengukuran hara tanaman hasil tertinggi selalu berada pada kelompok pengunaan pupuk organik hayati, hal ini semakin menguatkan pendapat bawasannya penggunaan pupuk organik hayati secara langsung dapat meningkatkan kemampuan tanaman menyerap kebutuhan hara tanaman. Pada pengukuran $\mathrm{N}$ tanaman dimana perlakuan kombinasi pupuk organik hayati dengan dosis pupuk N $150 \%$ menunjukkan hasil tertinggi, hal tersebut diduga efek dari penggunaan pupuk organik hayati yang dapat membantu memperbaiki kualitas fisik dan kimia media tanam. Berdasarkan penelitian Winarso (2005) kecepatan serapan hara oleh akar tanaman dipengaruhi oleh faktor-faktor seperti: kondisi fisik dan kimia, fase tumbuh tanaman, kecepatan tumbuh tanaman, cahaya matahari, suhu dan air.

Tabel 2. Pengaruh pupuk organik hayati pada bibit kelapa sawit terhadap kadar hara tanaman pada umur 12 MST

\begin{tabular}{|c|c|c|c|}
\hline \multirow{2}{*}{ Perlakuan } & $\mathrm{N}$ & $\mathrm{P}$ & K \\
\hline & \multicolumn{3}{|c|}{ 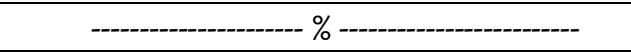 } \\
\hline \multicolumn{4}{|l|}{ Pengaruh Tunggal } \\
\hline Tanpa pupuk organik/hayati & $2.33^{\mathrm{a}}$ & $0.16^{c}$ & $2.15^{\mathrm{abc}}$ \\
\hline Pupuk organik & $2.36^{\mathrm{a}}$ & $0.17^{b c}$ & $2.23^{\mathrm{ab}}$ \\
\hline Pupuk organik hayati & $2.40^{\mathrm{a}}$ & $0.16^{c}$ & $2.43^{\mathrm{a}}$ \\
\hline \multicolumn{4}{|l|}{ Pengaruh Kombinasi } \\
\hline Tanpa pupuk organik/hayati & $1.86^{\mathrm{b}}$ & $0.18^{\mathrm{abc}}$ & $2.07^{\mathrm{b}}$ \\
\hline Pupuk N (dosis 50\%) & $2.34^{\mathrm{b}}$ & $0.19^{\mathrm{ab}}$ & $1.89^{c}$ \\
\hline Pupuk N (dosis 100\%) & $2.54^{\mathrm{b}}$ & $0.19^{a b}$ & $2.25^{\mathrm{a}}$ \\
\hline Pupuk N (dosis $150 \%$ ) & $2.76^{\mathrm{b}}$ & $0.19^{\mathrm{ab}}$ & $1.97^{\mathrm{c}}$ \\
\hline Pupuk Organik & $2.53^{\mathrm{b}}$ & $0.18^{a b c}$ & $1.99^{c}$ \\
\hline Pupuk Organik + Pupuk N (dosis 50\%) & $2.32^{\mathrm{ab}}$ & $0.17^{\mathrm{bc}}$ & $2.31^{\mathrm{a}}$ \\
\hline Pupuk Organik + Pupuk N (dosis 100\%) & $2.35^{\mathrm{ab}}$ & $0.16^{\mathrm{c}}$ & $2.14^{\mathrm{abc}}$ \\
\hline Pupuk Organik + Pupuk N (dosis 150\%) & $2.58^{\mathrm{b}}$ & $0.17^{b c}$ & $2.43^{a}$ \\
\hline Pupuk Organik Hayati & $1.87^{\mathrm{b}}$ & $0.19^{\mathrm{ab}}$ & $2.13^{\mathrm{abc}}$ \\
\hline Pupuk Organik Hayati + Pupuk N (dosis 50\%) & $2.46^{\mathrm{ab}}$ & $0.20^{\mathrm{a}}$ & $2.25^{\mathrm{a}}$ \\
\hline Pupuk Organik Hayati + Pupuk N (dosis 100\%) & $2.54^{\mathrm{b}}$ & $0.17^{\mathrm{bc}}$ & $2.52^{\mathrm{a}}$ \\
\hline Pupuk Organik Hayati + Pupuk N (dosis $150 \%$ ) & $2.82^{\mathrm{b}}$ & $0.17^{\mathrm{bc}}$ & $2.24^{\mathrm{a}}$ \\
\hline
\end{tabular}

Keterangan : angka-angka yang diikuti oleh huruf yang sama pada kolom yang sama berbeda tidak nyata menurut uji Duncan Multiple Range Test $5 \%$.

Hasil analisa statistik terhadap kadar $\mathrm{P}$ tanaman menunjukkan hasil yang berbeda nyata dengan hasil terbaik ditunjukkan oleh perlakuan pupuk organik hayati 
dengan pupuk $\mathrm{N}$ dosis $50 \%$. Hasil tertinggi terdapat pada 3 (tiga) kelompok perlakuan tanpa dan dengan penggunaan pupuk organik hayati, hal ini menunjukkan pengukuran $\mathrm{P}$ tanaman tidak terpengaruh oleh pengelompokkan perlakuan pupuk organik hayati. Menurut Premono et al. (1994), sifat P di dalam tanah terdapat dalam berbagai bentuk persenyawaan yang sebagian tidak tersedia bagi tanaman, sehingga pemberian pupuk organik/hayati dapat membantu proses mineralisasi P dalam tanah.

Selanjutnya hasil analisis statistik terhadap kadar K tanaman bibit kelapa sawit memberikan pengaruh yang nyata dibandingkan dengan semua perlakuan. Hasil terbaik ditunjukkan oleh perlakuan pupuk organik hayati dengan dosis pupuk N 100 $\%$, hal ini diduga karena dengan penambahan pupuk $\mathrm{K}$ dalam bentuk $\mathrm{KCl}$ kedalam tanah dapat meningkatkan kadar $\mathrm{K}$ dalam tanaman sehingga peningkatan $\mathrm{K}$ dalam tanaman seiring dengan peningkatan $\mathrm{K}$ dalam tanah. Pada analisa pengaruh tunggal pupuk organik/hayati hasil data menunjukkan bahwa pada aplikasi penggunaan pupuk oragnik/hayati terhadap kadar hara $\mathrm{P}$ dan $\mathrm{K}$ tanaman menunjukkan hasil yang berbeda nyata. Pada pengukuran hara $\mathrm{P}$ penggunaan pupuk organik hayati menunjukkan hasil terbaik meski berbeda tidak nyata dengan perlakuan tanpa penggunaan pupuk organik/hayati, sedangkan pada pengukuran kadar hara $\mathrm{K}$ hasil terbaik masih ditunjukkan oleh aplikasi penggunaan pupuk organik hayati dan berbeda nyata dengan semua perlakuan. Hal ini semakin menguatkan dugaan bahwa penggunaan agen hayati pada media tanam akan dapat signifikan mendukung pertumbuhan tanaman khususnya pada pengukuran kadar hara tanaman. Peningkatan jumlah mikrob tanah dapat meningkatkan ketersediaan hara tanah dalam bentuk yang tersedia sehingga dapat diasimilasi oleh tanaman. Diketahui beberapa mikrob tanah mampu menghasilkan hormon tanaman yang dapat merangsang pertumbuhan tanaman. Hormon yang dihasilkan oleh mikrob akan diserap oleh tanaman sehingga tanaman akan tumbuh lebih cepat atau lebih besar. Kelompok mikrob yang mampu menghasilkan hormon tanaman, antara lain: Pseudomonas sp dan Azotobacter sp. (Yu et al., 2018).

\section{KESIMPULAN}

Mikrob penambat $\mathrm{N}$ yang terdapat didalam pupuk organik hayati meningkatkan tinggi tanaman dan diameter batang yang nyata pada pembibitan kelapa sawit. Penggunaan pupuk N dosis 100 \% bersama pupuk organik hayati menunjukkan hasil keragaan tanaman terbaik.

\section{UCAPAN TERIMA KASIH}

Ucapan terima kasih kepada Kementrian Ristekdikti untuk pendanaan kegiatan ini melalui Hibah DRPM Penelitian Terapan Anggaran 2019 


\section{DAFTAR PUSTAKA}

Agung T, dan Rahayu AT. (2004). Analisis efisiensi serapan N, pertumbuhan dan hasil beberapa kultivar kedelai unggul baru dengan cekaman kekeringan dan pemberian pupuk hayati. Agribisnis. 6 (2): 70-74.

Kiswanto, Purwanta J.H, Wijayanto B. (2013). Teknologi Budidaya Kelapa Sawit. Balai Pengkajian Teknologi Pertanian. Bandar Lampung.

Lee, Sunhee, Reth A, Meletzus D, Sevilla M, Keneddy C. (2000). Characterization of a major cluster of nif, fix and associated genes in sugarcane endhopyte, Acetobacter diazhotropicus. Bacteriology. 182 (24) : 7088 - 7091.

Li, M., H.Y. Zhang., X.K. Zhou., C.G. Yang., S.C. Zheng., J.L. Duo., M.H. Mo. (2018). Biological control tobacco bacterial wilt and black shank and root colonization by bio-organic fertilizer containing bacterium Pseudomonas aeruginosa NXHG29. Applied Soil Ecology. Vol. 129, pp. 136-144.

Nan, L., S. Wu., Q. Guo., J. Wang., C. Cao., J. Wang. (2018). Leaf nitrogen assimilation and partitioning differ among subtropical forest plants in response to canopy addition of nitrogen treatments. Science of The Total Environment. Vol. 637638, pp. 1026-1034

Premono, M.E., Widyastuti, R., Anas, I. (1994). Pengaruh bakteri pelarut Fosfat terhadap serapan kation unsur mikro tanaman jagung pada tanah masam. Makalah PIT Permi. 31 Juli 1992. Bandung.

Rizwan, A., and A.I. Mahmood. (2017). Optimization of organic and bio-organic fertilizers on soil properties and growth of pigeon pea. Scientia Horticulturae. Vol. pp. 1-9.

Roca, L.F., J. Romero., J.M. Bohórquez., E. Alcántara., R. Fernández-Escobar., A. Trapero. (2018). Nitrogen status affects growth, chlorophyll content and infection by Fusicladium oleagineum in olive. Crop Protection. Vol. 109, pp. 8085

Wu, Y. (2017). Chapter 9 - Periphyton: A Promising Bio-Organic Fertilizer Source in Agricultural Ecosystems. Periphyton. Functions and Application in Environmental Remediation. Pp. 225-249

Yu, W., X. Zhao., Z. Guo., Z. Jia., S. Wang., K. Ding. (2018). Response of soil microbes to a reduction in phosphorus fertilizer in rice-wheat rotation paddy soils with varying soil P levels. Soil and Tillage Research. Vol. 181, pp. 127-135

Yue, W., C. Zhao., J. Farmer., J. Sun. (2015). Effects of bio-organic fertilizer on pepper growth and Fusariumwilt biocontrol. Scientia Horticulturae. Vol. 193, pp. 114120. 